\title{
Determinants of Profit Variability among Micro and Small Enterprises (MSEs) in Zambia
}

\author{
Yordanos Gebremeskel ${ }^{1}$ \\ ${ }^{1}$ Department of Economics, Mulungushi University, Kabwe, Zambia \\ Correspondence: Yordanos Gebremeskel, Department of Economics, Mulungushi University, Box. 80415, \\ Kabwe, Zambia. E-mail: yorsink@yahoo.com or yordanosge@gmail.com
}

Received: April 8, 2014

Accepted: May 22, 2014

Online Published: July 25, 2014

doi:10.5539/ijef.v6n8p129

URL: http://dx.doi.org/10.5539/ijef.v6n8p129

\begin{abstract}
Micro and Small Enterprises (MSEs) in developing economies like Zambia are major contributors of livelihood, job creation, poverty reduction, production and distribution of goods and services, and foreign exchange earnings. All these benefits could be realized if firms are profitable. This paper tried to envisage sources of variations in profitability among micro and small enterprises. By conducting an empirical study using 187 micro and small sized firms selected from four sectors: Trading, Services, Manufacturing, and Agriculture, the paper analyzed the sources of variations in firm profit across time. The study was made with selected firm-level characteristics like sales, cost, market coverage and perception about the level of competition. The analysis is done by using both descriptive statistics and an Ordered Probit Regression Model. Although measuring profit directly is difficult, alternative variables like changes in sales, revenue, cost, competition and market coverage are used. The estimation result revealed that, among firm effects, variations in sales and market coverage over time are the significant variables that explain variations in firm's profitability.
\end{abstract}

Keywords: micro and small enterprises, profitability, Ordered Probit model, Zambia

\section{Introduction}

Micro and Small Enterprises (MSEs) represent a larger percentage of businesses in many countries and they are drivers of the growth of an economy. Generally speaking, they comprise a variety of firms which possess a wide range of skills and operate in most sectors of the economy with different market, social and institutional arrangements. The range goes from a home-based unregistered business (informal) to a formal enterprise engaged in international businesses. Despite the heterogeneity, they are independent business establishments formed for profit making and are mostly managed by the owner/s.

The profit motive of the business enterprise is a fundamental factor for their existence. Many business decisions are normally made based on their impact on profitability (Medvedev \& Ana, 2013.) Profitability further determines the success and survival of the firm (Katayama et al., 2009). An existing business is making a profit or feeling there is a profit or is with a hope of making it. Where most of the MSEs are not keeping book of records, it is not as such easy to say they exist because they are making profit. Though that is the case, the sentiment of 'there is profit in the business' and a promising environment for profit and growth are essential for existing firms and new entrants. Whether the profit is real, perceived or potential, the critical question here is what determines the profit of firms among MSEs which ultimately determines their survival and existence in the market (or industry). The information is pivotal to assess what constitutes enterprise's profitability and their existence in the market.

Most empirical researchers evaluate the determinants of business profit from two angles. Those factors which are internal (controllable) to the firm and those which are external (uncontrollable) market environment factors in which they are operating. The internal one also called the Firm-effect model looks at the unique firm-specific characteristics such as heterogeneity in resources and competences and also the differences in corporate and competitive strategies on profitability. Whereas, the second approach argues profitability of the business by large depends on the structure of the industry under which the business operates.

Insight of the arguments above, understanding the economic, market environment, and firm-level characteristics in which the MSEs are operating is critical to understand the challenges and opportunities these firms are facing. 
This study attempted to investigate the firm-level determinants of variations in profit across time among MSEs in Zambia based on sampled and surveyed enterprises from Lusaka and Kabwe towns. The paper hypothesized that a firm experiencing a consistent increase in sales makes more profit. The study specifically had the following two objectives. To assess the performance of business enterprises as measured by indicators like sales/revenue, cost, profit, market coverage and competition; and to look at the determinants of profitability using a regression model.

The remainder of the research is organized as follows. Section two examines the theoretical and empirical evidence of business enterprise performance with a focus on determinants of profit. Section three and four discusses the data collection process and the econometric model. Results and discussions are presented in section five. Section six is for summary and conclusions.

\section{Theoretical Literature Review and Model}

\subsection{Profit and Determinants of Profit}

In classical economics framework, a firm is perceived as a profit maximizing entity. Despite the heterogeneity of their nature, all are in the market primarily to make a profit. Profit is measured by deducting cost from revenue. In the context of micro and small enterprises, the major components of cost are raw materials, wage bills, electricity and communication cost (Daniels, 2001). Revenue is calculated as a product of quantity sold and per unit price. If profit can be measured accurately, the information can be used to evaluate the success/performance of the enterprise (De Mel et al., 2009). Nevertheless, measuring profit is a very difficult task for researchers mainly because of the fact that most of the micro and small enterprises do not keep financial records (Daniels, 2001; De Mel et al., 2009). A stylized fact, in many literature reviews is that more profitable firms grow, whereas the less profitable firms decline (Alex \& Werner, 2010). Profitability increases the comparative advantage of the firm. A profitable firm has the means to finance expansion, aspire to grow, employing more people, and survive longer than the unprofitable ones.

Profit leads to business growth. Growth better explained in terms of profits (McPherson, 1996). A profitable and growing firm performs better than the rest of the group. Contemporary bodies of literatures explain firm performance in terms of profitability either using the Structure-Conduct-Performance (SCP) model or the Firm Effect model. According to the SCP model, the underlying industry (or market) structure (Note 1) determines firm conduct (Note 2) (behavior/strategy), which concerns the firm's ability to differentiate its goods and services and thus to influence the price it can charge. Industry structure and firm conduct combine to determine firm performance. Under this model, firms are considered more or less the same and the difference in performance is because of the market structure. This is to say firms enjoy profitability in a tight Oligopoly kind of market structure than a very competitive market structure. In short, SCP model assumes that there are relationships between the structure of markets, the conduct of firms, and the performance of firms (Carlton \& Perloff, 2000, p. 4).

On the other hand, the Firm-effect model captures the influence of the unique firm-specific characteristics such as heterogeneity in resources and competences and also the differences in corporate and competitive strategies on performance (Houthoofd \& Hendrickx, 2012). These constitute both tangible and intangible (measurable and immeasurable) competencies of the firm. Resources that are valuable, rare, inimitable, and non-substitutable can achieve sustainable competitive advantage by implementing fresh value-creating strategies that are difficult for competitors to duplicate (Barney, 2002). These could include intellectual property, process know-how, customer relationships, and the knowledge possessed by groups of specially skilled employees. In firm specific school of thought, the cardinal assumption is that Variation in profitability is largely due to persistent differences across firms (Stierwald, 2010). Firms with different cost structure exhibit varied level of profit.

Previous empirical researches studied the determinants of profitability with either SCP or firm-effect or using both frameworks. By and large, these studies are from the non-third-world economies on established business enterprises using official financial reports. Only a limited number of researches are conducted in developing countries, where financial reports are not easily accessible, on the performance of MSEs. This study seeks to look at the role of firm-specific factors in profitability of MSEs by employing quantitative methods from qualitative responses collected on the performance of enterprises. The paper adds to literature in the following three ways. Firstly, it adds to the ongoing exercise of researching what determines the profitability of a business firm. Secondly, it is an academic exercise of linking theory with realities. The study also contributes to the literature given the fact that there are only limited researches done on the profitability of MSEs of African economies. 


\subsection{Model Specification}

Choices, decisions or assessment in which the responses for the dependent variable are qualitative are better analyzed with Ordinal models often by probit or logit models (Note 3). The two most common and widely applied models for ordered dependent variables are ordered probit and ordered logit. The two models are by large similar and the difference comes when the regression coefficients are interpreted.

\subsection{The Ordered Probit Model}

The ordered probit model involves qualitative responses for the dependent variable in which the response categories have some order or ranking. The codes 1,2,3, and so on simply reflects the ranking and does not mean the difference between 1 and 2 is the same/equivalent to the difference between 2 and 3 .

The ordered probit model can be shown as follows. Suppose $\mathrm{y}^{*}$ is an unobservable index determined as;

$$
y^{*}=\alpha+\sum \beta_{i} X_{i}+u_{i}
$$

Where is the summation is over $\mathrm{i}=1, \ldots, \mathrm{k}$, the $\mathrm{X}_{\mathrm{i}}$ 's are $\mathrm{k}$ independent variables and $u$ is the disturbance term. The dependent variable has $\mathrm{J}+1$ categories so that instead of observing $\mathrm{y}^{*}$ we observe

$$
\begin{gathered}
y=0 \text { if } y^{*}<\delta_{0} \\
y=1 \text { if } \delta_{0}<y^{*} \leq \delta_{1} \\
y=2 \text { if } \delta_{1}<y^{*} \leq \delta_{2} \\
y=J \text { if } \delta_{J}-1<y^{*}
\end{gathered}
$$

the $\delta$ 's are unknowns 'threshold parameters that must be estimated along with $\alpha$ and the $\beta_{i}$ 's. Estimation is undertaken by Maximum Likelihood, which in the case of the ordered probit model requires that $u$ be assumed to be distributed as a standard normal.

The probability of obtaining an observation with $\mathrm{y}=0$ is equal to

$$
\begin{aligned}
& \operatorname{Prob}\left\{y^{*}=\alpha+\sum \beta_{i} X_{i}+u \leq \delta_{0}\right\} \\
& =\operatorname{Prob}\left\{u \leq \delta_{0}-\alpha-\sum \beta_{i} X_{i}\right\} \\
& =\int_{-\infty}^{\delta_{0}-\alpha-\sum \beta_{i} X_{i}} f(u) d u
\end{aligned}
$$

Where $f(u)$ is the standard normal density function. The probability of obtaining an observation with $\mathrm{y}=1$ is equal to

$$
\begin{aligned}
& \operatorname{Prob}\left\{\delta_{0}<y^{*}=\alpha+\sum \beta_{i} X_{i}+u \leq \delta_{1}\right\} \\
& =\operatorname{Prob}\left\{\delta_{0}-\alpha-\sum \beta_{i} X_{i}<u \leq \delta_{1}-\alpha-\sum \beta_{i} X_{i}\right\} \\
& =\int_{\delta_{0}-\alpha-\sum \beta_{i} X_{i}}^{\delta_{1}-\alpha-\sum \beta_{i} X_{i}} f(u) d u
\end{aligned}
$$

and so on.

The likelihood function is the product of such expressions for each of the data points, maximizing this function with respect to $\alpha$, the $\beta$ 's, and the $\delta$ 's produces the maximum likelihood estimates. When $\alpha \neq 0$ so that an intercept is included in the equation for $\mathrm{y}^{*}$, identification is achieved by setting $\delta_{0}$ equal to zero; specifying that has mean zero and variance one is also done for purposes of identification (William \& Peter,1992).

\section{Method, Data and Results \& Discussions}

\subsection{MSME in Zambia}

Over the past decade, Zambia's economy has been one of the fastest growing in Africa. The economy grew by an average of $6.1 \%$ over the period 2003 to 2011 (OECD, 2012). Gross Domestic product (GDP) per capita rose by $80 \%$ between 2000 and 2010 (Sutton and Gillian, 2013). Behind this impressive performance, the role of Micro and Small Enterprises (MSEs) has been indisputably significant. Based on the Zambia Business Survey (ZBS) and Labor Force Survey (LFS), it is estimated that the total number of MSMEs in Zambia was 1,050,000 which is composed of 1,020,000 (97\%) from the informal (Note 4) sector and 29,350 (3\%) from the formal sector. They account for 88 percent of the 4.1 million people employed. More than two-third (70\%) of the MSMEs are in agriculture, $21 \%$ in retail or wholesale trade, $3 \%$ in manufacturing, $2 \%$ are in hotels, food, and beverage, and the remaining $4 \%$ are engaged in other economic activities (George et al., 2010).

\subsection{Method and Data Collection}

Three complementary research methods were employed under this study. Initial semi-structured interviews were 
conducted to help identify key issues (including perceptions) pertaining to MSE development in Zambia. Focus group discussions with a cross-section of stakeholders from the MSE, and private, public and non-governmental offices working with MSEs were also carried out to help validate and understand issues emerging from literature review and from the semi-structured interviews, and to inform the design of the main research method and tool. The main research method under the study was in-depth one-on-one interviews conducted on sampled MSE enterprises from Lusaka and Kabwe. These interviews were largely structured, but included some semi-structured questions to allow for probing and explore for emerging issues not previously envisaged during research design.

Data was collected from two districts of Zambia, from Lusaka in Lusaka province and Kabwe in Central province. The data collection time was in December 2012. Lusaka is one of the oldest districts in Zambia, having been established about 100 years ago. It is now the country's administrative, commercial and industrial center, with a population of 1.75 million, density of 4,841 per $\mathrm{km}^{2}$ and growing at a rate of 4.9 percent per annum. The district includes what should be the widest spectrum of income and occupation categories. Kabwe is the provincial center of the Central Province and is on the main highway connecting Lusaka to the country's copper producing areas of the Copperbelt and North-west provinces. With a population of 203,000 and density of 129 per $\mathrm{km}^{2}$, Kabwe has experienced one of the slowest population growth rates (1.7 percent per annum) due to the demise of mining industries due to depletion of ore. Inhabitants have had to identify alternative livelihoods, resulting in the emergence of a wide range of small-scale enterprise activities.

In selecting the sample, the study stratified the MSEs by industrial sector. The sectors chosen were Agricultural, Manufacturing, Trading and Service sectors. Although, the study initially intended to use a proportionate random sample from the 4 sectors, this proved difficult as the comprehensive list of the MSEs provided by the Zambia Chamber of Commerce (ZCC) and Zambia Development Agency (ZDA) were found to be inadequate as most enterprises had either collapsed or could not be accessed. As a result, the study randomly selected 187 MSEs with each MSE having an equal chance of being included in the sample.

\subsubsection{Variables Selection}

Selected variables

Competition: The number and strength of competitors in the market affect the level of the firm's profit. Profitable markets attract new entrants, which erodes profitability. Intensity of competition determines profitability.

Cost: All costs that can be factored in as the firm's expenses. These include labor, rent, equipment, taxes, and overhead costs

Market coverage (share): Market coverage determines profitability. As the firm reaches to many customers profit will increase.

Sales: An increase in sales is essential in increasing the firm's profitability.

Business age: It is measured in years from the starting year (birth) of the firm to the time of the survey. The number of years in the business is expected to have an impact on the variation of profit levels. The relationship could be positive or negative.

\subsection{Results and Discussions}

\subsubsection{Descriptive Statistics}

A total of 187 MSEs were interviewed and of which 127 are from Lusaka and 60 from Kabwe. 80 percent of these firms are micro (Note 5) enterprises and half of them are operating as a sole proprietorship. The largest representation is from the trading sector (31 percent) followed by Services (27 percent), processing /manufacturing (15percent), Others (17 percent) and Agriculture ( 7 percent). 76 percent of the businesses are owned by men and 45 percent are in the business for more than 5 years. They have employed 1,346 people (69 percent male) that makes the average employment roughly 8 persons.

As a measurement of enterprise performance, respondents were asked to compare their current position against the start up time in terms of business performance parameters total sales/revenue, total cost, profit, market coverage and level of competition. $73.6 \%, 65 \%, 69.2 \%$, and $74.7 \%$ of the respondents said their enterprises had experienced an increase in total sales/revenue, profit, market coverage, and competition respectively. In comparison to the enterprises total cost of running the business against the start-up time, $76.4 \%$ of the respondents said cost has increased. In general, more than two-third of the respondents felt that all the indicated parameters had increased when they compared against the start up position. On the other hand, the remaining one-third said the business had experienced either a decrease or no-change for the specified indicator. 
Table 2. Comparison of current enterprise's position to start-up time

\begin{tabular}{lccc}
\hline & \multicolumn{3}{c}{ Performance indicators } \\
\cline { 2 - 4 } Variable & Increased & Decreased & Not Changed \\
\hline Sales/Revenue & 73.6 & 14.3 & 11.5 \\
Cost & 76.4 & 6.6 & 16.5 \\
Profit & 65 & 17.8 & 16.7 \\
Market Coverage & 69.2 & 11.1 & 17.4 \\
Competition & 74.7 & 3.5 & 21.2 \\
\hline
\end{tabular}

Table 2 revealed a mixed outcome. More firms reported that their cost is increasing than those reported revenue is increasing and at the same time they are claiming that the profit is increasing. As argued earlier, most firms exist in the business either by making a profit or by perceiving that there is a profit or with the hope of making it sometime in future. This is to say that a firm could report that it is making a profit while that might not be the case. Though the increase in total sales/revenue, profit, market coverage and competition can be seen as a good performance for the MSEs role in employment creation, income generation, and economic growth, the large percentage of firms experiencing increased total cost of running their business could have inversely affect their role in the economy.

Table 3 shows the relationship between the age of the business and the variation in profit. All firms, $100 \%$, who were in business only for less than 12 months reported that they have higher profit than the start-up days. If they are compared against those firms aged more than a year, new firms reported an increase in profit than the older ones. One reality is that for the young firms the time is too short to make a comparison of profit levels. Nevertheless the response revealed the high optimism the new firms have about the market.

When we exclude those firms aged less than a year we have a very different picture. For those firms aged 12 months and above in the business, the majority of them, $62 \%$ to $65 \%$, reported as they experienced increased profit now as compared to the start-up time. $16 \%$ to $19 \%$ reported no variation in profit and $16 \%$ to $20 \%$ experienced a decrease in profit across time.

Table 3. Cross tabulation of business-age against profit comparison

\begin{tabular}{lccc}
\hline & \multicolumn{3}{c}{ Current profit level as compared to start-up } \\
\cline { 2 - 4 } \multicolumn{1}{c}{ Business Age } & Increased & No change & Decreased \\
\hline Less than 1 year (7 firms) & 7 & 0 & 0 \\
$1-5$ years (88 firms) & 55 & 16 & 17 \\
$6-10$ years (44 firms) & 28 & 7 & 9 \\
More than 10 years (37 firms) & 24 & 7 & 6 \\
\hline
\end{tabular}

\subsubsection{Regression Result}

An econometric model is applied to investigate factors explaining variations in firms profit across time (Decreased, Has not changed, or Increased) as reported by the respondents from the time of establishment against the current period. Since getting responses for profit levels is difficult, the researcher used an alternative approach to get ordered responses and respondents were asked to describe the change from then to now. The explanatory variables considered to explain the variation in profit are sales/revenue, market coverage, cost, business related training, and ownership of more than one business. (Refer Annex I: Table 1 Description of variables)

The regression analysis is made using STATA ${ }^{\circledR}$ statistical software. The likelihood ratio chi-square of 85.92 with a p-value of 0.0000 shows that the model as a whole is statistically significant, as compared to the null model with all the listed predictors have no impact on the dependent variable. The estimation further shows that an increase in current market coverage as compared to start-up stage is a significant variable with p-value of 0.008 in explaining the variation in the profit level experienced by the firm across time. Given the profit change is ordinally measured by respondents as decreased, no-change, or increased; the ordered probit market coverage coefficient 0.740 is positively related to upward change in profit level and can be interpreted as a one unit increase in market coverage (i.e., as the enterprise's market coverage increases across time) the probability of change in profit is by 74 percent. The variable sales/revenue is also statistically highly significant with a $p$ value of 0.000 . The other important indicator variables of profit variability are the total cost of running the business 
and the level of competition. The higher the cost the tougher for firms to increase profits. The same is true for competition. The coefficients of the variables have a negative sigh. Business age, a variable that measures the total year of the business in operation. The variable has a negative sign with a size of 0.043 . All the three variables are not statistically significant.

Table 4. The ordered probit regression result

\begin{tabular}{|c|c|c|c|c|c|c|}
\hline \multicolumn{7}{|c|}{ Ordered probit regression Number of obs $=159$} \\
\hline \multicolumn{7}{|c|}{$\operatorname{LR} \operatorname{chi}^{2}(5)=85.92$} \\
\hline \multicolumn{7}{|c|}{ Prob $>$ chi $^{2}=0.0000$} \\
\hline \multicolumn{7}{|c|}{ Log likelihood $=-101.53115$} \\
\hline \multicolumn{7}{|c|}{ Pseudo $\mathrm{R}^{2}=0.2973$} \\
\hline Profit & Coefficients & Std. Err. & $\mathrm{Z}$ & $\mathrm{P}>|\mathrm{Z}|$ & {$[95 \%$ confi } & e interval] \\
\hline Sales/Revenue & .975478 & .1599032 & 6.10 & $0.000^{*}$ & .6620735 & 1.288882 \\
\hline Market coverage & .7403328 & .1714401 & 4.32 & $0.008^{*}$ & .4043164 & 1.076349 \\
\hline Competition & -.1193832 & .2152678 & -0.55 & 0.579 & -.5413003 & .302534 \\
\hline Business age & -.043577 & .1290849 & -0.34 & 0.736 & -.2965788 & 2094248 \\
\hline Cost & -.2011678 & .1983132 & -1.01 & 0.310 & -.5898546 & .187519 \\
\hline
\end{tabular}

Note. $*$ The Variables are statistically significant at $99 \%$ of confidence level.

The high chi $^{2}$ statistic implies that the independent variables used are explaining a great proportion of the variation in firm profit. Cost, revenue and market coverage are good predictors for variations in profit level. The estimation shows that sales and market coverage have positive signs whereas cost has a negative sign. These outcomes are consistent with economic theories of the business firm. A firm having increased market coverage and sales is more likely to have increased profit. This evidence is confirmed by the results of the ordered probit estimation at the 1 percent level of significance. This is a highly significant effect. This implies that those firms experiencing an increase in market coverage and sales have higher probability of having more profit for a given cost. On the other hand cost and profit are inversely related. The insignificance of cost on variation in profit levels may depict that the MSEs have almost similar cost structure. If that is the case cost cannot be a major source of variation in profit. Future researches might bring another insight to this end.

The estimation found that Business age and profit are negatively related. Those firms stayed for long in the business, say for more than 1 year, reported that their profit level declined as compared to the start up time than those firms who stayed for a shorter period, say less than 1year. This outcome is very interesting. Older firms reported that earlier periods in the business were where they got more profit just like as firms currently at their earliest entry also report the same. Generally speaking, for the given sample of firms business age and profit are inversely related with a very small magnitude. Most previous research found mixed results of business age and profitability relations.

\section{Conclusion}

Profit making is a principal objective of any business firm. This paper examined the sources of variation in profit levels across time using firm-level variables. Getting actual profit data from MSEs is difficult, if not impossible, in developing countries where the majority of them are not keeping book of records. Though that is the fact an attempt was made using qualitative responses generated from variables measuring profit of a business firm. Data was collected from 187 micro and small firms from two districts of Zambia, from Lusaka in Lusaka province and Kabwe in Central province. The majority of the firms represents trading, service, processing/manufacturing, and agriculture sectors.

The paper finds that most firms revealed that they experienced an increase in cost, sales, market coverage, competition, revenue and profit currently as they are compared to the start-up time. The regression analysis established that sales and market coverage have a direct and significant link with profit. Furthermore the paper finds that level of competition, cost, and business age are negatively related to profit. Regarding business age, both old and new firms reported that the earliest time of the business establishment is period of higher profits. This indicates that the business environment is not disappointing for new entrants. This is very important for growth and long-term survival. Although profitability depends on a number of economic and non-economic variables, the paper established that businesses capable of expanding their sales and market coverage across time gets more profit. Policies directed at creating a conducive environment for MSEs to grow through expanding 
their market would help them to be profitable.

While the results from this study are important additions to the ongoing exercise of understanding what makes micro and small enterprises profitable in the market, it should be treated as a basis for future studies on understanding MSEs dynamics and the broader MSE sector. The sector is so diverse in terms of the nature of competition, opportunities for expansion, business strategies and so on. Therefore more research is needed in this area (i) to identify the cost structure of MSEs (ii) to understand the opportunities and challenges for expansion of market coverage and (iii) to measure the magnitude of competition in the MSEs sub-sector.

\section{Acknowledgments}

This paper was part of the study conducted on 'The State of Business Practices an the Impact of BDS on MSMEs in Lusaka and Kabwe, Zambia' and supported by a grant from the Investment Climate and Business Environment (ICBE) Research Fund, a collaborative initiative of TrustAfrica and IDRC. I am thankful to Professor Tenkir Bonger and Mr Christian Chileshe who gave me a chance to participate in the project. I am also grateful to my colleagues Professor Tenkir Bonger \& Mr Willson Zimba and my wife Tsegewein Woubetu for their thorough review of the manuscript before it was sent for the publisher.

I am also grateful to the editorial team and the reviewrs of IJEF for their appropriate and constructive suggestions. The reviews were detailed and helpful to finalize the paper.

The publication fee of this article is fully covered by Mulungushi University.

\section{References}

Barney, J. (2002). Gaining and sustaining competitive advantage (2nd ed.). Upper Saddle River, NJ: Prentice Hall.

Carlton, D. W., \& Perloff, J. M. (2000). Modern Industrial Organization (3rd ed.). London: Addison Wesley.

Charles, H. (2003). The contribution of Micro-enterprises to economic recovery and poverty alleviation in East Asia. Economics Working Paper Series, WP 03-07.

Chong, H., \& Prairie, V. (2008). Measuring performance of small-and-medium sized enterprises: the grounded theory approach. Journal of Business and Public Affairs, 2(1).

Coad, A., \& Holzl, W. (2010). Firm Growth: Empirical Analysis. WIFO Working Papers, No. 361.

Daniels, L. (2001). Testing Alternative Measures of Microenterprise Profits and Net Worth. Journal of International Development, 13(5), 599-614. http://dx.doi.org/10.1002/jid.781

De Mel, S., McKenzie, D., \& Woodruff, C. (2009). Measuring Microenterprise Profits: Must We Ask How the Sausage is Made? Journal of Development Economics, 88(1), 19-31. http://dx.doi.org/10.1016/j.jdeveco.2008.01.007

George, R., Manju, K., Marie, S., Juliet, M., \& Roland, P. (2010). Zambia Business Survey: The Profile and Productivity of Zambian Businesses.

Hansen, S., \& Birger, W. (1989). Determinants of Firm Performance: The Relative Importance of Economic and Organizational Factors. Strategic Management Journal, 10(5), 399-411. http://dx.doi.org/10.1002/smj.4250100502

Houthoofd, N., \& Hendrickx, J. (2012). Industry Segment Effects and Firm Effects on Firm Performance in Single Industry firms. In R. Sanchez \& H. Aimé (Eds.), A Focused Issue on Competence Perspectives on New Industry Dynamics (Vol. 6, pp. 237-264). Emerald Group Publishing Limited. http://dx.doi.org/10.1108/S1744-2117(2012)0000006010

Katayama, H., Lu, S., \& Tybout, J. (2009). Firm-level Productivity Studies: Illusions and a Solution. International Journal of Industrial Organization, 27(3), 403-413. http://dx.doi.org/10.1016/j.ijindorg.2008.11.002

Maddala, G. S. (1983). Limited Dependent and Qualitative Variables in Econometrics. Cambridge Univesrsity Press. http://dx.doi.org/10.1017/CBO9780511810176

McPherson, M. A. (1996). Growth of Micro and Small Enterprises in Southern Africa. Journal of Development Economics, 48, 253-277. http://dx.doi.org/10.1016/0304-3878(95)00027-5

Medvedev, D., \& Oviedo, A. M. (2013). Informality and Profitability: Evidence from a New Firm Survey in Ecuador. World Bank. 
OECD. (2012). Investment Policy Reviews: Zambia.

Scherer, F. M., \& Ross, D. (1990). Industrial market structure and economic performance (3rd ed.). Boston: Houghton Mifflin.

Stierwald, A. (2010). Determinants of Profitability: An Analysis of Large Australian Firms. Melbourne Institute Working Paper, No. 3/10. http://dx.doi.org/10.2139/ssrn.1632749

Sutton, J., \& Gillian, L. (2013). An Enterprise Map of Zambia. International Growth Centre.

William, B., \& Peter, K. (1992). A Graphical Exposition of the Ordered Probit. Econometric Theory, 8(1), $127-$ 131. http://dx.doi.org/10.1017/S0266466600010781

\section{Notes}

Note 1. Market structure is mostly explained by variables like number of firms (sellers), barriers of entry, and degree of product differentiation. Other factors like location and availability of essential raw materials, nature of production technology, degree of work force unionization, durability of product, price elasticity of demand, availability of substitutes, growth and variability of demand also determine the market structure (Carlton and Perloff, 2000).

Note 2. Variables explaining conduct include pricing strategies, collusion, advertising, research and development, and capacity investment (Ibid).

Note 3. Probit or Logit model is used when the responses are binary or dichotomous. On the other hand when the responses are more than two but limited, the analysis requires consideration of another special model of Probit or Logit (Maddala, 1983; William and Peter, 1992).

Note 4. The informal sector is defined as those not registered by Patents and Companies Registration Agency (PACRA) or any other similar organization in Zambia.

Note 5 . As measured by number of employees, where those with 1-10 persons are micro, 11-50 persons are small and those with $51-100$ persons are medium.

\section{Appendix A. Description of Variables Used in the Regression Model}

\begin{tabular}{ll}
\hline Dependent Variable & \\
\hline Profit & $\begin{array}{l}\text { Ordinal variable equals } 0 \text { if the business experienced a decrease in profit as current period compared to startup } \\
\text { period, or equals } 1 \text { if the business experienced no change in profit as current period compared to startup period, or } \\
\text { equals } 2 \text { if the business experienced an increase in profit as current period compared to startup period. }\end{array}$ \\
\hline Independent Variables & \\
\hline Business age & Categorical variable equals 1 if the firm is in business for less than 1 year, or equals 2 for 1-5 years, or equals 3 \\
for more than 5 years up to 10 years, or equals to 3 for more than 10 years. \\
Market coverage & $\begin{array}{l}\text { Ordinal variable equals } 0 \text { if the business experienced a decrease in market coverage as current period compared to } \\
\text { startup period, or equals } 1 \text { if the business experienced no change in market coverage as current period compared } \\
\text { to startup period, or equals } 2 \text { if the business experienced an increase in market coverage as current period } \\
\text { compared to startup period. } \\
\text { Ordinal variable equals } 0 \text { if the business experienced a decrease in sales as current period compared to startup } \\
\text { period, or equals } 1 \text { if the business experienced no change in sales as current period compared to startup period, or } \\
\text { equals } 2 \text { if the business experienced an increase in sales as current period compared to startup period. } \\
\text { Ordinal variable equals } 0 \text { if the business experienced a decrease in cost as current period compared to startup } \\
\text { period, or equals } 1 \text { if the business experienced no change in cost as current period compared to startup period, or } \\
\text { equals } 2 \text { if the business experienced an increase in cost as current period compared to startup period. }\end{array}$ \\
\end{tabular}

\section{Copyrights}

Copyright for this article is retained by the author(s), with first publication rights granted to the journal.

This is an open-access article distributed under the terms and conditions of the Creative Commons Attribution license (http://creativecommons.org/licenses/by/3.0/). 